\title{
Natural regeneration in a restored bauxite mine in southeast Brazil
}

\author{
Regeneración natural en mina de bauxita restaurada en el sureste de Brasil
}

\section{Aurino Miranda Neto a*, Sebastião Venâncio Martins a, Kelly de Almeida Silva a ${ }^{\text {, }}$ Aldo Teixeira Lopes ${ }^{b}$, Raul de Abreu Demolinari ${ }^{b}$}

\author{
* Corresponding author: ${ }^{a}$ Universidade Federal de Viçosa, Departamento de Engenharia Florestal, Laboratório de Restauração \\ Florestal (LARF), Campus Universitário - CEP: 36570900 - Viçosa, MG, Brasil, aur.neto@gmail.com \\ botorantim Metais, Setor de Meio Ambiente, CEP: 36790000, Miraí, MG, Brasil.
}

\begin{abstract}
SUMMARY
The objective of the present study was to verify if, in floristic terms of natural regeneration, a restored bauxite mine in southeast Brazil can be considered successfully restored. Forty plots of $3.0 \times 3.0 \mathrm{~m}$ were allocated in the area. All shrubs and trees with height $\geq 0.30 \mathrm{~m}$ and diameter at $1.30 \mathrm{~m}$ height $(\mathrm{DBH}) \leq 5.0 \mathrm{~cm}$ were identified and classified into successional categories and dispersal syndromes; DSL (diameter at soil level) and height were measured. We use the canonical correspondence analysis (CCA) to verify the correlations between environmental variables (canopy openness, litter decomposition, soil penetration resistance) and vegetation. We found 705 individuals, 80 species and 30 families. The families with the highest species richness were Fabaceae and Melastomataceae. The specie with the highest importance value (IV) was Myrcia splendens. Most species are the early secondary successional category and the zoochoric dispersion syndrome. CCA ordination indicates the formation of a group of species associated with less soil compaction and with low litter decomposition rate and the formation of another group associated with intermediate values of soil penetration resistance and litter decomposition rate. The results obtained after ten years of implementation of the restoration project, in floristic terms, are suitable. In other words, the area can be considered as successfully restored.
\end{abstract}

Key words: bauxite, canonical correspondence analysis, floristic, forest restoration.

\section{RESUMEN}

El objetivo del presente estudio fue verificar si, en términos florísticos de la regeneración natural, una mina de bauxita restaurada en el sureste de Brasil puede considerarse restaurada con éxito. En el área, se distribuyeron 40 parcelas de 3,0 x 3,0 m, donde todos los arbustos y los árboles con altura $\geq 0,30 \mathrm{~m}$ y diámetro a $1,30 \mathrm{~m}$ de altura (DAP) $\leq 5,0 \mathrm{~cm}$ fueron identificados, medido el diámetro a nivel del suelo y la altura, y clasificados en categoría sucesional y dispersión de semillas. Se aplicó análisis de correspondencia canónica (CCA) para verificar las correlaciones entre variables ambientales y vegetación. Se encontraron 705 individuos, 80 especies y 30 familias. Las familias con mayor riqueza de especies fueron Fabaceae y Melastomataceae, y la especie con el mayor valor de importancia fue Myrcia splendens. La mayoría de las especies fueron de la categoría de sucesión secundaria inicial y con dispersión de semillas por zoocoría. Las variables ambientales mostraron los valores: constante de descomposición de la hojarasca $(\mathrm{k})(0,0033 \pm 0,0017)$; apertura del dosel $(8,1 \pm 6,5 \%)$; resistencia a la penetración $(9,3 \pm 4,6 \mathrm{MPa})$. La ordenación CCA indicó la formación de un grupo de especies asociadas con menos compactación del suelo y con una baja tasa de descomposición de la hojarasca, y la formación de otro grupo asociado con valores intermedios de resistencia a la penetración y la descomposición de la hojarasca. Los resultados obtenidos después de 10 años de ejecución del proyecto de restauración, en términos florísticos, son adecuados. Se puede considerar que el área fue restaurada con éxito.

Palabras clave: bauxita, análisis de correspondencia canónica, florística, restauración forestal.

\section{INTRODUCTION}

Forests have been degraded over time by increasing human activities and they are quickly shrinking (Lu et al. 2011). After undergoing a disturbance such as mining, the forest ecosystem loses its floristic composition and biotic means of regeneration, which will prevent it from returning to its original natural condition (Rodrigues et al. 2010). Ore extraction causes onus, evidenced by the in- tense alteration of the environment, both with reference to the local landscape and physical and temporal depth. The mining of bauxite causes the destruction of vegetation, altering the soil and landscape conditions and disrupting the ecosystem (Moreira 2004).

In this scenario, it is necessary to recover the degraded ecosystem by forest restoration techniques considered effective tools of ecological engineering (Lu et al. 2011). Forest restoration aims at restoring natural ecological pro- 
cesses and structures of a degraded or altered forest (Deluca et al. 2010), seeking the return of pre-disturbance conditions (van Andel and Aronson 2012).

To succeed in a forest restoration project, it is essential to perform the evaluation of the restored area by the analysis of indicators or environmental variables (Brancalion et al. 2012). The evaluation indicators of forest restoration most commonly used are the vegetative indicators or bioindicators such as natural regeneration, seed rain, soil seed bank, canopy openness, litter production and nutrient cycling (Martins 2013).

The study of natural regeneration can predict the subsequent behavior and development of the forest, because regeneration enables the understanding of the relationship and the number of species belonging to its stock, along with their dimensions and distributions in the forest (Carvalho 1982). This understanding provides important information about the ecology of individual species (Newton 2007), and whether there is the need for interventions aimed at accelerating the successional process as planting enrichment and elimination of exotic species (Martins and Kunz 2007).

In restoration projects conducted by planting tree and shrub species, natural regeneration has a key role in the occupation of spaces among seedlings by propagules that arrive in the area, coming from planted species and the surrounding forest fragments.

In trees, the most common age group evaluated in restoration projects is $1-15$ years (about $70 \%$ ) (Wortley et al. 2013). Vegetation structure, species diversity and abundance, and ecological processes are the most commonly used attributes to indicate the ecosystem condition in the process of restoration (Wortley et al. 2013). Restoration of mined areas and their evaluation, as in bauxite mine, are becoming increasingly common and important throughout the world (Parrotta et al. 1997, Grant et al. 2007, Kew et al. 2007, Koch 2007).

Parrotta et al. (1997), in evaluating the understory of a bauxite mine 10 years after the planting of native tree species in the Brazilian Amazon region, showed that the restoration has been largely successful in establishing a dynamic and sustainable successional environment. In addition, the natural regeneration layer was formed from seed dispersal by planted trees and forest areas in the surroundings.

The present study investigates the relation of environmental variables with the floristic composition of natural regeneration layers in a restored bauxite mine, and tests the hypothesis that the area, in floristic terms, can be considered successfully restored.

\section{METHODS}

Study site. The current study was conducted in a restored bauxite mine by planting tree seedling $\left(21^{\circ} 25^{\prime} 35^{\prime \prime} \mathrm{S}\right.$, $42^{\circ} 56^{\prime} 08$ ” W), in the county of Descoberto, Minas Gerais State, in southeast Brazil, with altitude between 618 - $633 \mathrm{~m}$ (figure 1).

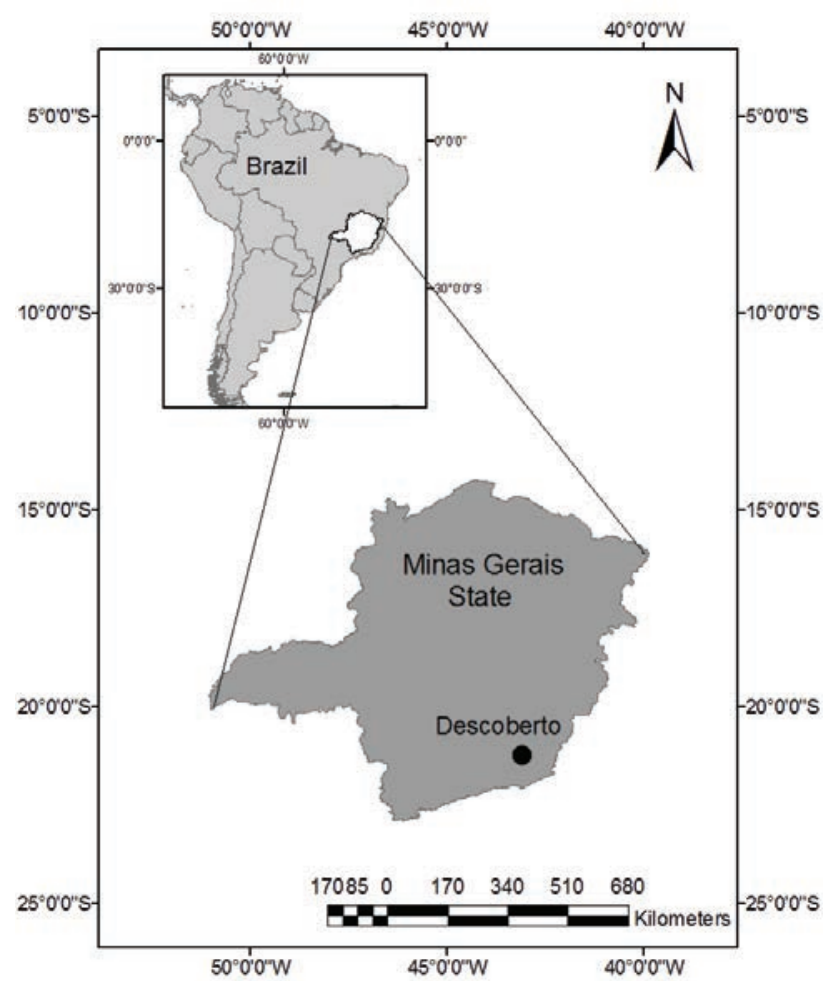

Figure 1. Study site, county of Descoberto, Minas Gerais State, Brazil.

Sitio de estudio, la ciudad de Descoberto, Minas Gerais, Brasil.

The climate of the region is classified as Aw (tropical humid) by the Koeppen system. The temperature is high in summer, reaching $40^{\circ} \mathrm{C}$, and in winter it is $20-22^{\circ} \mathrm{C}$. Average annual rainfall is $1,300 \mathrm{~mm}$. It has a very rugged topography, with small plains and plateaus limited by mountains and rectilinear valleys (Lopes and Branquinho 1988). The predominant vegetation in the region where the study area is inserted is classified as semideciduous montane forest (IBGE 2012).

In 2003, Votorantim Metais Company explored bauxite in the study area. Subsequently, yet in 2003, the topographic reconstruction process was held with the return of topsoil removed before mining and the implementation of forest restoration through the planting of trees in the total area (1.0 ha), with spacing of $1.0 \times 1.0 \mathrm{~m}$ (table 1). Maintenance activities were held: correction of soil acidity; phosphate fertilizer; topdressing around each seedling; regular combat to ants with granular bait. The study of the floristic composition of natural regeneration layer was performed in 2013.

Around the study area, there are areas undergoing restoration with different ages, grasslands and preserved forest fragments.

Vegetation characterization. In the study area, 40 permanent plots of $3.0 \times 3.0 \mathrm{~m}$ were allocated, at intervals of 10 $\mathrm{m}$ between the plots. All the shrubs and trees with height 
Table 1. List of tree species used in planting.

Lista de especies de árboles utiliza en la siembra.

\begin{tabular}{|c|c|c|c|}
\hline Family & Specie & SC & DS \\
\hline Achariaceae & Carpotroche brasiliensis (Raddi) A Gray & LS & Zoo \\
\hline \multirow[t]{2}{*}{ Arecaceae } & Euterpe edulis Mart. & LS & Zoo \\
\hline & Syagrus romanzoffiana (Cham.) Glassman & ES & Zoo \\
\hline \multirow[t]{3}{*}{ Bignoniaceae } & Handroanthus heptaphyllus (Vell.) Mattos & LS & Ane \\
\hline & Zeyheria tuberculosa (Vell.) Bureau ex Verl. & ES & Ane \\
\hline & Sparattosperma leucanthum (Vell.) K.Schum. & ES & Ane \\
\hline Cannabaceae & Trema micrantha (L.) Blume & $\mathrm{P}$ & Zoo \\
\hline Chrysobalanaceae & Licania tomentosa (Benth.) Fritsch & ES & Zoo \\
\hline Euphorbiaceae & Joannesia princeps Vell. & ES & Auto \\
\hline \multirow[t]{14}{*}{ Fabaceae } & Anadenanthera peregrina (L.) Speg. & ES & Ane \\
\hline & Caesalpinia peltophoroides Benth. & ES & Auto \\
\hline & Cassia ferruginea (Schrad.) Schrad. ex DC. & ES & Auto \\
\hline & Clitoria fairchildiana R.A.Howard & ES & Auto \\
\hline & Dalbergia nigra (Vell.) Allemão ex Benth. & ES & Ane \\
\hline & Hymenaea courbaril L. & LS & Zoo \\
\hline & Inga vera Willd. & ES & Zoo \\
\hline & Senna multijuga (Rich.) H.S.Irwin et Barneby & ES & Auto \\
\hline & Senna macranthera (DC. ex Collad.) H.S.Irwin et Barneby & $\mathrm{P}$ & Auto \\
\hline & Plathymenia reticulata Benth. & ES & Ane \\
\hline & Piptadenea gonoacantha (Mart.) J. F. Macbr & ES & Auto \\
\hline & Anadenanthera colubrina (Vell.) Brenan & ES & Ane \\
\hline & Cassia grandis L. f. & ES & Ane \\
\hline & Platypodium elegans Vogel & ES & Ane \\
\hline Lecythidaceae & Cariniana estrellensis (Raddi) Kuntze & LS & Ane \\
\hline Malpighiaceae & Lophanthera lactescens Ducke & LS & Nc \\
\hline Malvaceae & Luehea grandiflora Mart. et Zucc. & ES & Ane \\
\hline Melastomataceae & Tibouchina granulosa (Desr.) Cogn. & $\mathrm{P}$ & Zoo \\
\hline \multirow[t]{2}{*}{ Meliaceae } & Cedrela fissilis Vell. & LS & Ane \\
\hline & Guarea guidonia (L.) Sleumer & LS & Zoo \\
\hline Moraceae & Artocarpus heterophyllus Lam. & Nc & Zoo \\
\hline \multirow[t]{4}{*}{ Myrtaceae } & Eugenia florida DC. & LS & Zoo \\
\hline & Myrcia splendens (Sw.) DC. & ES & Zoo \\
\hline & Syzygium cumini (L.) Skeels & $\mathrm{P}$ & Zoo \\
\hline & Psidium guajava L. & $\mathrm{P}$ & Zoo \\
\hline Phytolaccaceae & Gallesia integrifolia (Spreng.) Harms & ES & Zoo \\
\hline Rubiaceae & Genipa americana L. & LS & Zoo \\
\hline Urticaceae & Cecropia glaziovii Snethl. & $\mathrm{P}$ & Zoo \\
\hline
\end{tabular}

SC: successional category (P: pioneer, ES: early secondary, LS: late secondary); DS: dispersal syndrome (Ane: anemochory; Zoo: zoochory; Auto: autochory).

SC: categoría sucesional (P: pionero, ES: secundario inicial; LS: secundario tardío); DS: dispersión de semillas (Ane: anemócora; Zoo: zoócora; Auto: autócora). 
$\geq 0.30 \mathrm{~m}$ and diameter at breast height $(\mathrm{DBH}=1.30 \mathrm{~m})$ $\leq 5.0 \mathrm{~cm}$ were identified and DSL (diameter at soil level) and height were measured.

For species not identified in situ, the botanical material was collected for comparison to the material deposited in the herbarium VIC Federal University of Viçosa, after consulting with experts and literature.

The classification of species into families followed Angiosperm Phylogeny Group III (APG III, 2009). The nomenclature of the species and the abbreviations follow available information on the Missouri Botanical Garden (2014) and Lista de Espécies da Flora do Brasil (2014).

Phytosociological parameters (Mueller-Dombois and Ellenberg 1974) for describing the community structure were determined using the software FITOPAC 2.1 (Shepherd 2010). Jaccard similarity index (Mueller-Dombois and Ellenberg 1974) was used to verify the floristic similarity between species of regeneration and species planting.

Successional categories and dispersal syndromes. The species sampled were classified as successional categories according Gandolfi et al. (1995) for Brazilian semideciduous forests. Four successional categories that correspond to shade tolerant species were adopted: pioneer, early secondary, late secondary and unclassified. The more shade-tolerant species were included at the late secondary category. The shade-intolerant species were included at the pioneer category.

Species were also classified as to dispersal syndromes in four categories: zoochory, anemochory, autochory (van der Pijl 1982) and unclassified.

Environmental variables. Canopy openness was determined by digital hemispherical photographs acquired at the center of each plot with CI-110 Digital Plant Canopy Imager® equipment.

The degree of soil penetration resistance was measured by resistance to vertical penetration into the soil by an impact penetrometer (digital model Penetrolog PLG1020 Falker), using the cone type 2 in the 0 to $10 \mathrm{~cm}$ depth in each plot. Medium value of resistance was used to penetration in profile.

To measure litter decomposition, 40 litterbags with $5.0 \mathrm{~g}$ of dry mass of leaf litter were distributed in the study area. Decomposition rates were estimated from the loss of dry mass, during one year. The material obtained was dried in forced air oven at $343 \mathrm{~K}$ for 48 hours and the dry mass was measured in electronic precision scale. Afterwards, decomposition rate $\mathrm{k}$ was estimated according to equation 1 (Olson 1963).

$$
X t=X_{0} e^{-k t}
$$

Where, $\mathrm{Xt}=$ weight of litter at time $\mathrm{t} ; \mathrm{X}_{0}=$ initial weight of litter; $\mathrm{e}=$ natural logarithm; $\mathrm{k}=$ decomposition rate cons$\tan t ; \mathrm{t}=$ time of decomposition.
Statistical analyses. To analyze the correlations between the environmental variables and vegetation, the canonical correspondence analysis was employed; it was performed in software FITOPAC 2.1 (Shepherd 2010). Environmental variables and frequency values for 23 species (density $\geq$ five individuals) were used for the calculations, with subsequent removal of the species with no significant scores on both axes for more robust analyses. Thus, the number of species was reduced to 19. Correlations between the species axes and environmental variable axes were tested using Monte Carlo tests to estimate the significance of correlations among canonical axes.

\section{RESULTS}

Floristic composition. The floristic of the restored area was represented by 80 species belonging to 30 families. A total of 705 individuals were sampled in this forest $(19,583$ individuals ha-1), distributed in 13,555 trees $\mathrm{ha}^{-1}$ and 3,888 shrubs ha ${ }^{-1}$ (table 2).

The families with the highest species richness were Fabaceae (13) and Melastomataceae (12). The families with the most important number of individuals were Melastomataceae, with 263 individuals and Myrtaceae, with 182. They corresponded with $63.1 \%$ of the total of plants sampled.

There are 21 common species between regeneration and species used in planting, with a Jaccard similarity index of 0.21 between planting and regeneration.

The species with the highest importance values (IV) that characterized this restored area were Myrcia splendens, $\mathrm{Hy}$ menaea courbaril, Miconia tristis, Anadenanthera peregrina, Miconia cinnamomifolia, Licania tomentosa, Miconia sp., Siparuna guianensis, Miconia latecrenata and Syzygium cumini, representing $65.6 \%$ of the individuals (figure 2).

The average height value was $132 \pm 122 \mathrm{~cm}$, with minimum and maximum of 30 and $750 \mathrm{~cm}$, respectively. The average diameter value was $1.20 \pm 1.30 \mathrm{~cm}$, with minimum and maximum of 0.02 and $7.92 \mathrm{~cm}$, respectively.

Shannon diversity index $\left(H^{\prime}\right)$ was 3.20 and evenness $\left(J^{\prime}\right)$ was 0.73 .

Successional categories and dispersal syndromes. The shrub and tree species sampled in the restored area are distributed in 14 pioneer species, 30 early secondary species and 20 late secondary species; while 16 species could not be classified. Of the total of individuals sampled in the restored area, 197 were pioneer, 314 early secondary and 90 were late secondary; while 104 individuals were species unclassified (figure 3).

Regarding dispersal syndrome, the shrub and tree species sampled in the restored area are distributed in 47 zoochoric species, 13 anemochoric species and seven autochoric species; while 13 species could not be classified. Of the total of individuals sampled in the restored area, 548 were zoochoric, 38 were anemocoric and 19 were autochoric; while 100 individuals were unclassified species (figure 3). 
Table 2. Floristic and importance value (IV) of the species sampled in natural regeneration layer in restored area, Brazil.

Florística y valor de importancia (IV) de las especies muestreadas en el estrato natural de regeneración en la zona reforestada, Brasil.

\begin{tabular}{|c|c|c|c|c|c|c|}
\hline Family & Specie & $\mathrm{N}$ & IV \% & $\mathrm{LF}$ & SC & DS \\
\hline Achariaceae & Carpotroche brasiliensis (Raddi) A Gray & 2 & 0.34 & $\mathrm{~T}$ & LS & Zoo \\
\hline \multirow[t]{4}{*}{ Anacardiaceae } & Astronium concinnum Schott & 2 & 1.32 & $\mathrm{~T}$ & LS & Ane \\
\hline & Astronium graveolens Jacq. & 1 & 0.74 & $\mathrm{~T}$ & ES & Ane \\
\hline & Spondias mombin L. & 2 & 0.43 & $\mathrm{~T}$ & $\mathrm{U}$ & Zoo \\
\hline & Spondias venulosa (Engl.) Engl. & 1 & 0.21 & $\mathrm{~T}$ & $\mathrm{U}$ & Zoo \\
\hline \multirow[t]{3}{*}{ Annonaceae } & Xylopia sericea A.St.-Hil. & 13 & 2.12 & $\mathrm{~T}$ & ES & Zoo \\
\hline & Annona neosericea H.Rainer & 1 & 0.41 & $\mathrm{~T}$ & ES & Zoo \\
\hline & Annona sylvatica A.St.-Hil. & 1 & 0.39 & $\mathrm{~T}$ & ES & Zoo \\
\hline \multirow[t]{2}{*}{ Arecaceae } & Euterpe edulis Mart. & 1 & 0.17 & $\mathrm{~T}$ & LS & Zoo \\
\hline & Asteraceae & 3 & 0.72 & $\mathrm{U}$ & $\mathrm{U}$ & $\mathrm{U}$ \\
\hline Asteraceae & Vernonanthura divaricata (Spreng.) H.Rob. & 1 & 0.17 & $\mathrm{~S}$ & $\mathrm{P}$ & Ane \\
\hline \multirow[t]{3}{*}{ Bignoniaceae } & Zeyheria tuberculosa (Vell.) Bureau ex Verl. & 3 & 1.36 & $\mathrm{~T}$ & ES & Ane \\
\hline & Tecoma stans (L.) Juss. ex Kunth & 2 & 0.70 & $\mathrm{~T}$ & $\mathrm{P}$ & Ane \\
\hline & Handroanthus heptaphyllus (Vell.) Mattos & 2 & 0.37 & $\mathrm{~T}$ & LS & Ane \\
\hline Boraginaceae & Cordia sellowiana Cham. & 1 & 0.34 & $\mathrm{~T}$ & ES & Zoo \\
\hline Cannabaceae & Celtis sp. & 1 & 0.20 & $\mathrm{~T}$ & $\mathrm{U}$ & $\mathrm{U}$ \\
\hline Chrysobalanaceae & Licania tomentosa (Benth.) Fritsch & 19 & 4.35 & $\mathrm{~T}$ & ES & Zoo \\
\hline \multirow[t]{2}{*}{ Erythroxylaceae } & Erythroxylum pelleterianum A.St.-Hil. & 12 & 1.39 & $\mathrm{~T}$ & ES & Zoo \\
\hline & Erythroxylum deciduum A.St.-Hil. & 6 & 0.93 & $\mathrm{~T}$ & ES & Zoo \\
\hline \multirow[t]{3}{*}{ Euphorbiaceae } & Aparisthmium cordatum (A.Juss.) Baill. & 3 & 1.36 & $\mathrm{~T}$ & ES & Auto \\
\hline & Maprounea guianensis Aubl. & 6 & 1.02 & $\mathrm{~T}$ & ES & Auto \\
\hline & Alchornea glandulosa Poepp. et Endl. & 3 & 0.46 & $\mathrm{~T}$ & $\mathrm{P}$ & Zoo \\
\hline \multirow[t]{13}{*}{ Fabaceae } & Hymenaea courbaril L. & 11 & 5.56 & $\mathrm{~T}$ & LS & Zoo \\
\hline & Anadenanthera peregrina (L.) Speg. & 16 & 5.20 & $\mathrm{~T}$ & ES & Ane \\
\hline & Cassia ferruginea (Schrad.) Schrad. ex DC. & 5 & 1.55 & $\mathrm{~T}$ & ES & Auto \\
\hline & Dalbergia nigra (Vell.) Allemão ex Benth. & 3 & 1.44 & $\mathrm{~T}$ & ES & Ane \\
\hline & Inga vera Willd. & 2 & 1.26 & $\mathrm{~T}$ & ES & Zoo \\
\hline & Machaerium nyctitans (Vell.) Benth. & 2 & 0.81 & $\mathrm{~T}$ & ES & Ane \\
\hline & Senna multijuga (Rich.) H.S.Irwin et Barneby & 2 & 0.80 & $\mathrm{~T}$ & ES & Auto \\
\hline & Clitoria fairchildiana R.A.Howard & 1 & 0.70 & $\mathrm{~T}$ & ES & Auto \\
\hline & Apuleia leiocarpa (Vogel) J.F.Macbr. & 3 & 0.50 & $\mathrm{~T}$ & LS & Ane \\
\hline & Inga marginata Willd. & 1 & 0.49 & $\mathrm{~T}$ & ES & Ane \\
\hline & Caesalpinia leiostachya (Benth.) Ducke & 1 & 0.39 & $\mathrm{~T}$ & ES & Auto \\
\hline & Caesalpinia peltophoroides Benth. & 1 & 0.23 & $\mathrm{~T}$ & ES & Auto \\
\hline & Mimosa sp. & 1 & 0.17 & $\mathrm{U}$ & $\mathrm{U}$ & $\mathrm{U}$ \\
\hline Lacistemataceae & Lacistema pubescens Mart. & 2 & 0.35 & $\mathrm{~T}$ & ES & Zoo \\
\hline Lauraceae & Nectandra rigida (Kunth) Nees & 4 & 0.71 & $\mathrm{~T}$ & LS & Zoo \\
\hline \multirow[t]{2}{*}{ Malpighiaceae } & Byrsonima sericea DC. & 3 & 0.68 & $\mathrm{~T}$ & ES & Zoo \\
\hline & Lophanthera lactescens Ducke & 3 & 0.51 & $\mathrm{~T}$ & LS & $\mathrm{U}$ \\
\hline Malvaceae & Luehea grandiflora Mart. et Zucc. & 1 & 0.18 & $\mathrm{~T}$ & ES & Ane \\
\hline Melastomataceae & Miconia tristis Spring & 66 & 5.42 & $\mathrm{~S}$ & $\mathrm{P}$ & Zoo \\
\hline
\end{tabular}


Table 2 continue

\begin{tabular}{|c|c|c|c|c|c|c|}
\hline & Miconia cinnamomifolia (DC.) Naudin & 36 & 4.75 & $\mathrm{~T}$ & $\mathrm{P}$ & Zoo \\
\hline & Miconia sp. & 61 & 4.32 & $\mathrm{U}$ & $\mathrm{U}$ & $\mathrm{U}$ \\
\hline & Miconia latecrenata (DC.) Naudin & 43 & 3.09 & $\mathrm{~T}$ & $\mathrm{P}$ & Zoo \\
\hline & Miconia pusilliflora (DC.) Naudin & 20 & 2.35 & $\mathrm{~T}$ & ES & Zoo \\
\hline & Ossaea sp. & 11 & 1.10 & $\mathrm{~S}$ & $\mathrm{U}$ & $\mathrm{U}$ \\
\hline & Leandra nianga (DC.) Cogn. & 6 & 0.83 & $\mathrm{~S}$ & LS & Zoo \\
\hline & Miconia sellowiana Naudin & 7 & 0.64 & $\mathrm{~T}$ & $\mathrm{P}$ & Zoo \\
\hline & Leandra sericea DC. & 3 & 0.51 & $\mathrm{~S}$ & LS & Zoo \\
\hline & Miconia discolor DC. & 3 & 0.41 & $\mathrm{~S}$ & $\mathrm{U}$ & Zoo \\
\hline & Ossaea marginata (Desr.) Triana & 4 & 0.41 & $\mathrm{~S}$ & $\mathrm{U}$ & $\mathrm{U}$ \\
\hline & Leandra sp. & 3 & 0.32 & $\mathrm{~S}$ & $\mathrm{U}$ & $\mathrm{U}$ \\
\hline \multirow[t]{2}{*}{ Meliaceae } & Cedrela fissilis Vell. & 1 & 1.02 & $\mathrm{~T}$ & LS & Ane \\
\hline & Trichilia pallida Sw. & 1 & 0.15 & $\mathrm{~T}$ & LS & Zoo \\
\hline Moraceae & Artocarpus heterophyllus Lam. & 1 & 0.58 & $\mathrm{~T}$ & $\mathrm{U}$ & Zoo \\
\hline \multirow[t]{3}{*}{ Myrtaceae } & Myrcia splendens (Sw.) DC. & 178 & 13.00 & $\mathrm{~T}$ & ES & Zoo \\
\hline & Syzygium cumini (L.) Skeels & 3 & 2.62 & $\mathrm{~T}$ & $\mathrm{P}$ & Zoo \\
\hline & Eugenia florida DC. & 1 & 0.15 & $\mathrm{~T}$ & LS & Zoo \\
\hline \multirow[t]{3}{*}{ Piperaceae } & Piper arboreum Aubl. & 8 & 0.95 & $\mathrm{~S}$ & LS & Zoo \\
\hline & Piper mollicomum Kunth & 3 & 0.38 & $\mathrm{~S}$ & ES & Zoo \\
\hline & Piper sp. & 1 & 0.15 & $\mathrm{~S}$ & $\mathrm{U}$ & $\mathrm{U}$ \\
\hline Primulaceae & Myrsine coriacea (Sw.) R.Br. ex Roem. et Schult. & 4 & 0.61 & $\mathrm{~T}$ & ES & Zoo \\
\hline \multirow[t]{3}{*}{ Rubiacae } & Psychotria conjungens Müll.Arg. & 7 & 1.10 & $\mathrm{~S}$ & LS & Zoo \\
\hline & Psychotria nuda Cham. et Schltdl.) Wawra & 1 & 0.17 & $\mathrm{~S}$ & LS & Zoo \\
\hline & Amaioua guianensis Aubl. & 1 & 0.15 & $\mathrm{~T}$ & LS & Zoo \\
\hline Rutaceae & Zanthoxylum rhoifolium Lam. & 2 & 0.51 & $\mathrm{~T}$ & $\mathrm{P}$ & Zoo \\
\hline \multirow[t]{2}{*}{ Salicaceae } & Casearia gossypiosperma Briq. & 2 & 0.49 & $\mathrm{~T}$ & LS & Zoo \\
\hline & Casearia arborea (Rich.) Urb. & 2 & 0.43 & $\mathrm{~T}$ & ES & Zoo \\
\hline \multirow[t]{3}{*}{ Sapindaceae } & Matayba elaeagnoides Radlk. & 1 & 0.23 & $\mathrm{~T}$ & ES & Zoo \\
\hline & Allophylus edulis (A.St.-Hil.) Radlk. & 1 & 0.16 & $\mathrm{~T}$ & $\mathrm{P}$ & Zoo \\
\hline & Cupania ludowigii Somner et Ferrucci & 1 & 0.15 & $\mathrm{~T}$ & LS & Zoo \\
\hline Siparunaceae & Siparuna guianensis Aubl. & 30 & 4.23 & $\mathrm{~T}$ & LS & Zoo \\
\hline \multirow[t]{3}{*}{ Solanaceae } & Solanum leucodendron Sendtn. & 14 & 2.13 & $\mathrm{~S}$ & $\mathrm{P}$ & Zoo \\
\hline & Solanum cernuum Vell. & 9 & 1.18 & $\mathrm{~S}$ & $\mathrm{P}$ & Zoo \\
\hline & Solanum argenteum Dunal & 7 & 0.69 & $\mathrm{~T}$ & $\mathrm{P}$ & Zoo \\
\hline \multirow[t]{4}{*}{ Undetermined } & Undetermined 1 & 3 & 0.40 & $\mathrm{U}$ & $\mathrm{U}$ & $\mathrm{U}$ \\
\hline & Undetermined 2 & 4 & 1.31 & $\mathrm{U}$ & $\mathrm{U}$ & $\mathrm{U}$ \\
\hline & Undetermined 3 & 3 & 0.29 & $\mathrm{U}$ & $\mathrm{U}$ & $\mathrm{U}$ \\
\hline & Undetermined 4 & 2 & 0.54 & $\mathrm{U}$ & $\mathrm{U}$ & $\mathrm{U}$ \\
\hline Urticaceae & Cecropia glaziovii Snethl. & 3 & 1.02 & $\mathrm{~T}$ & $\mathrm{P}$ & Zoo \\
\hline Total & & 705 & 100.00 & & & \\
\hline
\end{tabular}

N: number of individuals; IV: importance value; LF: life form (T: tree, S: shrub); SC: successional category (P: pioneer, ES: early secondary, LS: late secondary); DS: dispersal syndrome (Ane: anemochory; Zoo: zoochory; Auto: autochory); U: unclassified.

$\mathrm{N}$ : número de individuos; IV: valor de importancia; LF: forma de vida (T: árbol, S: arbusto); SC: categoría sucesional (P: pionero, ES: secundario inicial; LS: secundario tardío); DS: dispersión de semillas (Ane: anemócora; Zoo: zoócora; Auto: autócora); U: sin clasificar. 


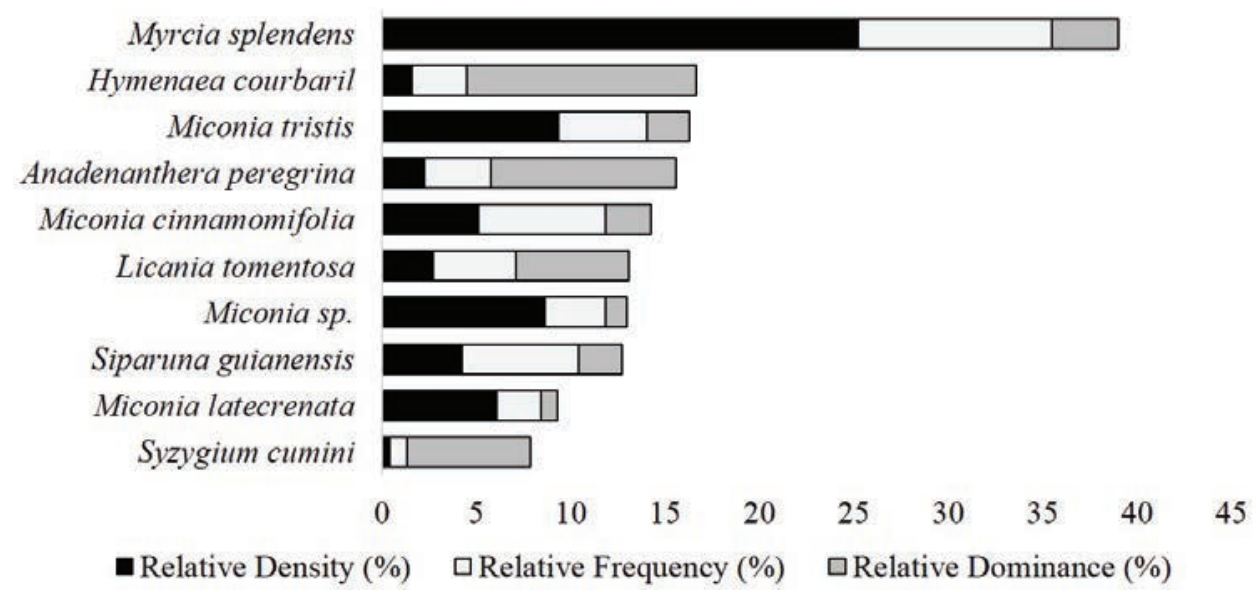

Figure 2. Species with the highest importance value (IV).

Especies com más altos valores de importancia (IV).

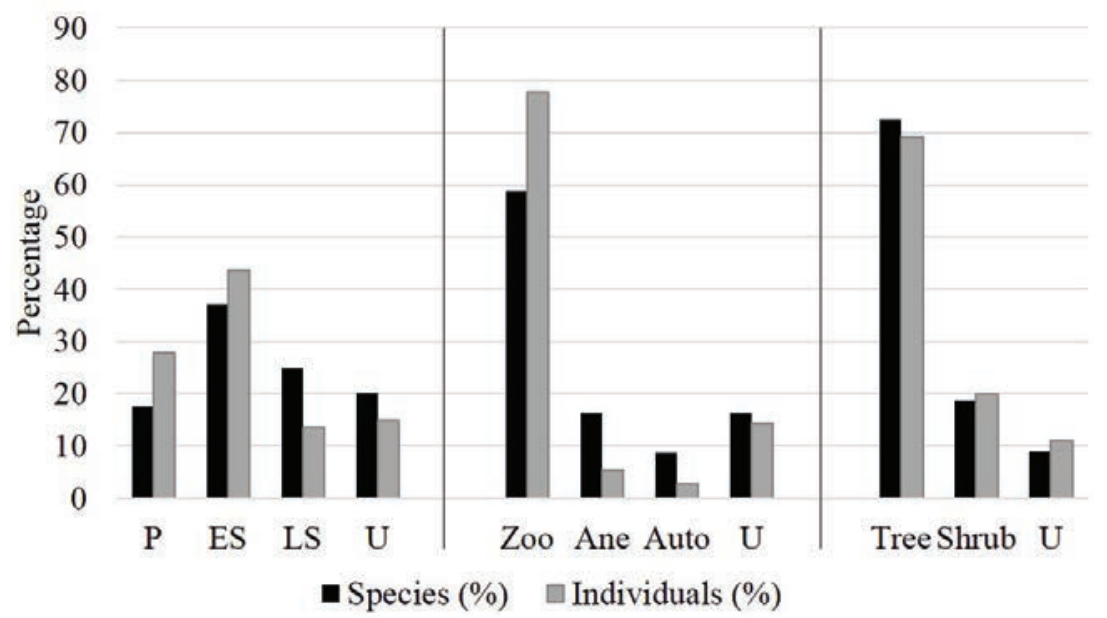

Figure 3. Percentual distribution of individuals and species to successional category (P: pioneer, ES: early secondary, LS: late secondary), dispersal syndrome (Ane: anemochory; Zoo: zoochory; Auto: autochory) and life form. U: unclassified.

Distribución porcentual de individuos y especies a la categoría sucesional (P: pionero, ES: secundario inicial; LS: secundario tardío), dispersión de semillas (Ane: anemócora; Zoo: zoócora; Auto: autócora) y forma de vida. U: sin clasificar.

Environmental variables and vegetation correlations. The environmental variables showed the following values: low leaf litter decomposition rate constant $(\mathrm{k})=0.0033$ \pm 0.0017 ; low canopy openness $=8.1 \pm 6.5 \%$; high soil penetration resistance $=9.3 \pm 4.6 \mathrm{MPa}$.

The species and the scores of axes 1 and 2 used in the canonical correspondence analysis are shown in table 3. The canonical correspondence analysis eigenvalues for the first two ordination axes were 0.354 (axis 1) and 0.145 (axis 2). In this analysis the first canonical axis explained $10.9 \%$ of the variance and the second axis explained $4.5 \%$, together accounting for $15.4 \%$ of the total variance. The Monte Carlo permutation test showed significance $(P=0.05)$ only for the species-environmental correlations between the first axes.
The environmental variables most strongly correlated with the first axis were leaf litter decomposition, and with the second axis were soil penetration resistance. The weighted correlations showed weak interrelations among the three variables, because they present eigenvalues lower than 0.5 (ter Braak 1995) (table 4).

The canonical correspondence analysis ordination (figure 4) indicates the formation of a group of species associated with less soil compaction and with low litter decomposition rate as Maprounea guianensis and Solanum Cernuum. And the formation of another group associated with intermediate values of soil penetration resistance and litter decomposition rate as Miconia pusilliflora and $\mathrm{Hy}$ menaea courbaril. Solanum leucodendron tended towards higher abundance in more open canopy. Miconia latecre- 
Table 3. The species, abbreviated species name and scores of axes 1 and 2 used in the canonical correspondence analysis. Especies, nombre de las especies abreviado y las puntuaciones de los ejes 1 y 2 utilizadas en el análisis de correspondencia canónica.

\begin{tabular}{|c|c|c|c|}
\hline \multirow{2}{*}{ Species } & \multirow{2}{*}{$\begin{array}{l}\text { Abbreviated } \\
\text { Species name }\end{array}$} & \multicolumn{2}{|c|}{ Scores } \\
\hline & & Axis 1 & Axis 2 \\
\hline Cassia ferruginea (Schrad.) Schrad. ex DC. & Cas fer & -1.133 & 0.716 \\
\hline Erythroxylum pelleterianum A.St.-Hil. & Ery pel & 0.322 & -1.414 \\
\hline Hymenaea courbaril L. & Hym cou & -0.133 & 0.700 \\
\hline Leandra nianga (DC.) Cogn. & Lea nia & -1.960 & -0.308 \\
\hline Maprounea guianensis Aubl. & Map gui & 0.476 & -1.085 \\
\hline Miconia cinnamomifolia (DC.) Naudin & Mic cin & 0.109 & 0.640 \\
\hline Miconia latecrenata (DC.) Naudin & Mic lat & 2.325 & 1.897 \\
\hline Miconia pusilliflora (DC.) Naudin & Mic pus & -1.419 & 0.695 \\
\hline Miconia sellowiana Naudin & Mic sel & -1.305 & -1.951 \\
\hline Miconia sp. & Mic sp. & 0.665 & -0.919 \\
\hline Miconia tristis Spring & Mic tri & -1.470 & 0.400 \\
\hline Myrcia splendens (Sw.) DC. & Myr spl & 0.214 & -0.565 \\
\hline Ossaea sp. & Oss sp. & -0.558 & 1.018 \\
\hline Piper arboreum Aubl. & Pip arb & -1.150 & 2.060 \\
\hline Psychotria conjungens Müll.Arg. & Psy con & 0.873 & 0.436 \\
\hline Solanum argenteum Dunal & Sol arg & -1.267 & 3.633 \\
\hline Solanum cernuum Vell. & Sol cer & 0.537 & -1.643 \\
\hline Solanum leucodendron Sendtn. & Sol leu & -0.809 & -0.217 \\
\hline Xylopia sericea A.St.-Hil. & Xyl ser & -0.256 & 0.613 \\
\hline
\end{tabular}

Table 4. Canonical correspondence analysis: internal correlations (intraset) in the first two ordination axes and correlation matrix weighted environmental variables used in the analysis. *Correlations with absolute values $>0.5$.

Análisis de correspondencia canónica (CCA): correlaciones internas ('intraset') en los dos primeros ejes de ordenación y de la matriz de correlación ponderados de los variables ambientales utilizados en el análisis. Las correlaciones con valores absolutos $>0,5$ se muestran en negrita.

\begin{tabular}{lccccc}
\hline \multirow{2}{*}{ Environmental variables } & \multicolumn{2}{c}{ Internal correlations } & \multicolumn{3}{c}{ Weighted correlations } \\
\cline { 2 - 6 } & Axis 01 & Axis 02 & $\mathrm{k}$ & Soil penetration resistance & Canopy openness \\
\hline $\mathrm{k}$ & $-0.9886^{*}$ & 0.0664 & 1.000 & - & - \\
Soil penetration resistance & -0.1317 & $-0.9913^{*}$ & 0.196 & 1.000 & - \\
Canopy openness & -0.3202 & -0.2575 & 0.176 & -0.215 & 1.000 \\
\hline
\end{tabular}

nata and Psychotria conjungens tended to higher abundance in more closed canopy. Piper arboreum and Solanum argenteum tended to higher abundance at sites with more compacted soils.

Concerning the distribution of plots, the canonical correspondence analysis ordination (figure 5) indicates that there is not a formation of large patches in the area with predominant characteristics of the studied environmental variables. The study area shows environmental heterogeneity.

\section{DISCUSSION}

Floristic composition. Fabaceae, Melastomataceae and Myrtaceae are botanical families often found in floristic surveys of natural regeneration in semideciduous forests (Higuchi et al. 2006, Marangon et al. 2008) and in restored areas (Santos and Valcarcel 2011, Miranda Neto et al. 2012).

Fabaceae is an important family in restoration areas, because many species of this family can perform biological nitrogen fixation, which eases the regeneration on 


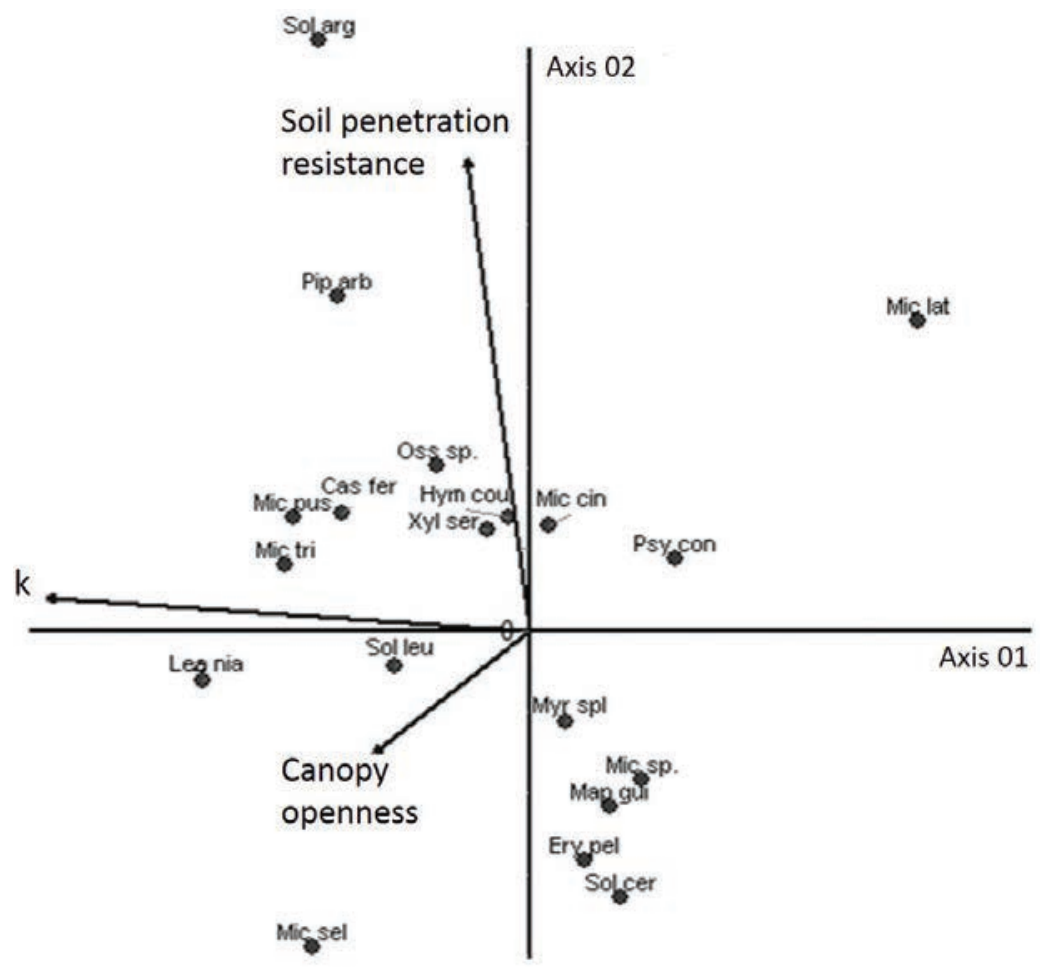

Figure 4. Canonical correspondence analysis ordination showing the distribution of species in relation to soil penetration resistance, leaf litter decomposition rate constant (k) and canopy openness. See table 2 for complete species names.

Ordenación del análisis de correspondencia canónica que muestra la distribución de las especies en relación a resistencia a la penetración, constante de velocidad de descomposición de hojarasca (k) y la apertura del dosel. Ver cuadro 2 para los nombres de especies completas.

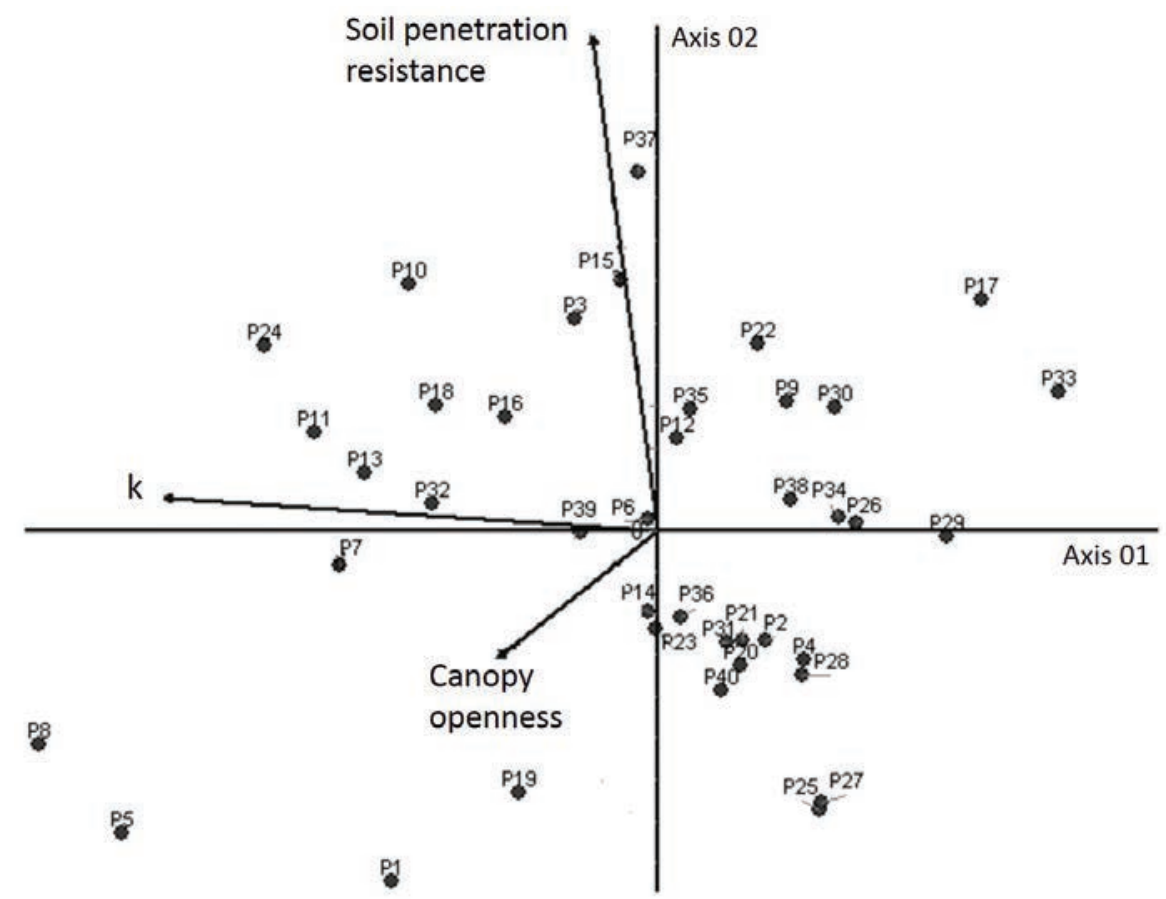

Figure 5. Canonical correspondence analysis ordination showing the distribution of plots in relation to soil penetration resistance, leaf litter decomposition rate constant $(\mathrm{k})$ and canopy openness.

Ordenación del análisis de correspondencia canónica que muestra la distribución de las unidades de muestreo en relación a resistencia a la penetración, constante de velocidad de descomposición de hojarasca (k) y la apertura del dosel. 
degraded soils (Campello 1998), as Dalbergia nigra (Dias et al. 2006), Inga marginata and Inga vera (Moreira e Siqueira 2006).

Melastomataceae gathers individuals with several life forms, with distribution in all Brazilian forest types (Baumgratz et al. 2010) and in degraded areas (Clausing and Renner 2001). It is considered the sixth largest family of angiosperms in Brazil (Forzza et al. 2010). In the Atlantic Forest, region of this study, this family is considered an important group due to the density of its populations (Baumgratz et al. 2006).

Myrtaceae is a botanical family with high occurrence in tropical and subtropical regions of the world (Lamarca et al. 2011) with about 3,800 species worldwide (Lucas et al. 2005) and about 1,000 species in Brazil (Sobral et al. 2010). Most species of this family are part of a late successional category (Hüller and Schock 2011).

There is no floristic similarity between the regeneration layer and the species used in planting since the degree of floristic similarity between two communities considered by the Jaccard index (Mueller-Dumbois and Ellenberg 1974) has not been reached: values equal to or higher than 0.25. Nevertheless, Fabaceae and Myrtaceae families are represented mainly by the species used in planting. This demonstrates an important contribution in the floristic composition of regeneration. Melastomataceae and Solanaceae have their most important representation of species from the surrounding forest fragments. This demonstrates that the restored area receives propagules of the forest matrix where it is inserted and provides a favorable environment for the development of these species from the surrounding.

The outstanding importance value presented by species Myrcia splendens is mainly related to its high relative density. This species was also sampled with emphasis on natural regeneration in secondary forest fragments in southeastern Brazil (Alves and Metzger 2006, Higuchi et al. 2006) and in restored areas (Miranda Neto et al. 2012).

Hymenaea courbaril and Anadenanthera peregrina stood out for their high basal area value. Despite the low number of individuals, these have large size, with high values of height and diameter compared with other species.

Hymenaea courbaril has a vast geographical distribution with adaptation to different environments (Silva-Júnior et al. 2001). Individuals of this species in the seedling and young stages are tolerant to shading. Young individuals also have good development in disturbed environments and in environments with high light incidence. This maximizes their use in conservation tactics and forest restoration projects (Oliveira et al. 2011).

Anadenanthera peregrina occurs in dry and wet soils; it tolerates shallow, compacted, poorly drained and soggy soils, with medium to clayey texture and shows moderate growth (Carvalho 2003). However, a strong dominance and allelopathic effects of Anadenanthera peregrina can contribute to a selective effect on the seed bank and re- generation, and decrease the diversity of shrub and tree species in monospecific plantations for forest restoration (Souza et al. 2012).

The values of Shannon diversity $\left(H^{\prime}\right)$ and evenness $\left(J^{\prime}\right)$ define a forest with medium diversity, low ecological dominance heterogeneous floristic to Semi-deciduous forest (Souza et al. 2013).

Successional categories and dispersal syndromes. The percentage of species and individuals by successional category in the restored area shows that the early secondary species were the most abundant ones. This result corroborates with findings in a 40 -year-old restored forest by Miranda Neto et al. (2012) and forest fragment by Higuchi et al. (2006), both located in the same region of this study, in which the larger proportion of the verified species was from the early secondary category. These data show an average successional stage for such environments and that the restored area got successional progress in the dynamics of ecological relations.

The percentage of species and individuals by dispersal syndromes in the restored area shows that the zoochoric species were the most abundant ones. More than $75 \%$ of trees in tropical forests have zoochoric dispersion (Beaune et al. 2013). This large presence of species with zoochoric dispersion is important for the maintenance of propagules disperser fauna, and shows a significant resource and shelter supply for the fauna (Franco et al. 2012).

Environmental variables and vegetation correlations. The average value of canopy openness did not present highvalue. It collaborates with the large presence in natural regeneration layer of species of secondary ecological group, which need shaded environment at least in the initial growth phase.

According to the classification of soil penetration resistance in forest environments proposed by Arshad et al. (1996), the average value found in this study falls under high compaction. This probably happened because the study area was severely altered by the bauxite mining and topsoil removal and, thus, it reached the lower layers in the soil profile with higher resistance to penetration. This severe alteration of the study area may also have a direct action on the low leaf litter decomposition rate constant. In an environment possessing high compaction, as the study area, the speed of lixiviation is low, and thus the leaf litter decomposition rate will be slower.

The first and second eigenvalue can be considered low, less than 0.5 (ter Braak 1995), showing the existence of a short gradient on the first and second axes (Carvalho et al. 2005).

The low eigenvalues show a remaining variance that is not explained by the environmental variables used. However, it is a common feature in vegetation data and does not affect the significance of the species-environment relationships (ter Braak 1995). This fact is proven by the Monte 
Carlo permutation test which showed that the abundances of species and environmental variables were significantly correlated, at least on the first axis.

Canonical correspondence analyses showed that the species analyzed have different behaviors in relation to environmental variables.

Miconia latecrenata is a pioneer species found in open areas (Fonseca et al. 2013). However, this species was associated with a more closed canopy sites. This was probably due to the concentration of $77 \%$ of individuals of this species in a single installment, where the value of canopy openness was only $4.3 \%$. This result shows that Miconia latecrenata can also develop and survive, at least in the initial phase, in environments with high levels of shading.

Piper arboreum is an understory plant (Bizerril and Raw 1998), found in disturbed areas. Its fruits are dispersed by bats (Mikich 2002). Solanum argenteum is a frequent species in natural regeneration layers of reforested degraded areas (Santos and Valcarcel 2011) and its main mechanism of dispersal is by fruit bats (Mikich 2002). These facts can explain the preference of these species for sites with high soil penetration resistance.

\section{CONCLUSIONS}

The floristic composition of the natural regeneration layer, mostly, can be divided into two groups. The first group is associated with less soil compaction and low litter decomposition rate and the second is associated with intermediate values of soil penetration resistance and litter decomposition rate.

The natural regeneration layer of the restored area shows progress in forest succession, and it can be classified as intermediate successional stage. For the mined area, the results obtained after ten years of implementation of the restoration project, in floristic terms, are suitable. In other words, we can consider that the area was successfully restored.

\section{ACKNOWLEDGMENTS}

The authors would like to thank CAPES and CNPq for grants, and the Votorantim Metais Company for financial support (project LARF-UFV/Votorantim Metais).

\section{REFERENCES}

Alves LF, JP Metzger. 2006. A regeneração florestal em áreas de floresta secundária na Reserva Florestal do Morro Grande, Cotia, SP. Biota Neotropica 6(2). Consultado 27 nov. 2013. Disponible en http://www.biotaneotropica.org.br/v6n2/pt/ abstract?article+bn00406022006

APG III (Angiosperm Phylogeny Group III). 2009. An update of the Angiosperm Phylogeny Group classification for the order sand families of flowering plants. Botanical Journal of the Linnean Society 161: 105-121.

Arshad MA, B Lowery, B Grossman. 1996. Physical tests for mo- nitoring soil quality. In Doran JW, AJ Jones eds. Methods for assessing soil quality. Madison, USA. Soil Science Society of America. p. 123-141.

Baumgratz JFA, KFR Bernardo, B Chiavegatto, R Goldenberg, PJF Guimarães, R Kriebel, AB Martins, FA Michelangeli, M Reginato, R Romero, MLDR Souza, E Woodgyer. 2010. Melastomataceae. In Forzza RC ed. Catálogo de plantas e fungos do Brasil. v. 02. Rio de Janeiro, Brasil. Jardim Botânico do Rio de Janeiro. p. 1236-1277.

Baumgratz JFA, MLDR Souza, DC Carraça, BA Abbas. 2006. Melastomataceae na Reserva Biológica de Poço das Antas, Silva Jardim, Rio de Janeiro, Brasil: aspectos florísticos e taxonômicos. Rodriguésia 57: 591-646.

Beaune D, F Bretagnolle, L Bollache, G Hohmann, M Surbeck, B Fruth. 2013. Seed dispersal strategies and the threat of defaunation in a Congo forest. Biodiversity and Conservation 22: 225-238.

Bizerril MXA, A Raw. 1998. Feeding behaviour of bats and the dispersal of Piper arboreum seeds in Brazil. Journal of Tropical Ecology 14(1): 109-114.

Brancalion PHS, RAG Viani, RR Rodrigues, S Gandolfi. 2012. Avaliação e monitoramento de áreas em processo de restauração. In Martins SV ed. Restauração ecológica de ecossistemas degradados. Viçosa, Brasil. Editora UFV. p. 262-293.

Campello EFC. 1998. Sucessão vegetal na recuperação de áreas degradadas. In Dias LE, LWV Mello eds. Recuperação de áreas degradadas. Viçosa, Brasil. Editora UFV. p. 183-196.

Carvalho DA, AT Oliveira-Filho, E van den Berg, MAL Fontes, EA Vilela, JJGSM Marques, WAC Carvalho. 2005. Variações florísticas e estruturais do componente arbóreo de uma floresta ombrófila alto-montana às margens do rio Grande, Bocaina de Minas, MG, Brasil. Acta Botanica Brasilica 19(1): 91-109.

Carvalho JOP. 1982. Análise estrutural da regeneração natural em floresta tropical densa na região do Tapajós no Estado do Pará. Tesis Magíster en Engenharia Florestal. Curitiba, Brasil. Universidade Federal do Paraná. 128 p.

Carvalho PER. 2003. Espécies arbóreas brasileiras. Colombo, Brasil. Embrapa Florestas. 1039 p.

Clausing G, SS Renner. 2001. Molecular phylogenetics of Melastomataceae and Memecylaceae: implications for character evolution. American Journal of Botany 88: 486-498.

Deluca TH, GH Aplet, B Wilmer, J Burchfield. 2010. The unknown trajectory of forest restoration: a call for ecosystem monitoring. Journal of Forestry 108(6): 288-295.

Dias PF, SM Souto, MEF Correia, GP Rocha, JF Moreira, KM Rodrigues, AA Franco. 2006. Árvores fixadoras de nitrogênio e macrofauna do solo em pastagem de híbrido de Digitaria. Pesquisa Agropecuária Brasileira 41(6): 1015-1021.

Fonseca SN, JHC Ribeiro, FA Carvalho. 2013. Estrutura e diversidade da regeneração arbórea em uma floresta secundária urbana (Juiz de Fora, MG, Brasil). Floresta e Ambiente 20(3): 307-315.

Forzza RC, JFA Baumgratz, CEM Bicudo, AA Carvalho Júnior, A Costa, DP Costa, M Hopkins, PM Leitman, LG Lohmann, LC Maia, G Martinelli, M Menezes, MP Morim, MAN Coelho, AL Peixoto, JR Pirani, J Prado, LP Queiroz, VC Souza, JR Stehmann, LS Sylvestre, BMT Walter, D Zappi. 2010. Catálogo de plantas e fungos do Brasil. v. 01. Rio de Janeiro, Brasil. Jardim Botânico do Rio de Janeiro. 1702 p.

Franco BKS, SV Martins, PCL Faria, GA Ribeiro. 2012. Den- 
sidade e composição florística do banco de sementes de um trecho de floresta estacional semidecidual no campus da Universidade Federal de Viçosa, Viçosa, MG. Revista Árvore 36(3): 423-432.

Gandolfi S, HF Leitão Filho, CLF Bezerra. 1995. Levantamento florístico e caráter sucessional das espécies arbustivo-arbóreas de uma floresta semidecídua no município de Guarulhos, SP. Revista Brasileira de Biololgia 55: 753-767.

Grant CD, SC Ward, SC Morley. 2007. Return of Ecosystem Function to Restored Bauxite Mines in Western Australia. Restoration Ecology 15(4): S94-S103.

Higuchi P, MGF Reis, GG Reis, AL Pinheiro, CT Silva, CHR Oliveira. 2006. Composição florística da regeneração natural de espécies arbóreas ao longo de oito anos em um fragmento de Floresta Estacional Semidecidual, em Viçosa, MG. Revista Árvore 30(6): 893-904.

Hüller A, AA Schock. 2011. Avaliação do potencial alelopático de três espécies de Eugenia L. (Myrtaceae) sobre o processo germinativo de Lactuca sativa L. Revista de Ciências Ambientais 5(1): 25-37.

IBGE (Instituto Brasileiro de Geografia e Estatística, BR). 2012. Manual Técnico da Vegetação Brasileira. $2^{\mathrm{a}}$ ed. Manuais Técnicos em Geociências. Rio de Janeiro, Brasil. Instituto Brasileiro de Geografia e Estatística. 275 p.

Kew GA, FC Mengler, RJ Gilkes. 2007. Regolith strength, water retention, and implications for ripping and plant root growth in bauxite mine restoration. Restoration Ecology 15(4): S54-S64.

Koch JM .2007. Restoring a Jarrah Forest Understorey Vegetation after Bauxite Mining in Western Australia. Restoration Ecology 15(4): S26-S39.

Lamarca EV, CV Silva, CJ Barbedo. 2011. Limites térmicos para a germinação em função da origem de sementes de espécies de Eugenia (Myrtaceae) nativas do Brasil. Acta Botanica Brasilica 25(2): 293-300.

Lista de Espécies da Flora do Brasil. Jardim Botânico do Rio de Janeiro. Consultado 11 mar. 2014. Disponible en http:// floradobrasil.jbrj.gov.br/

Lopes RF, JA Branquinho. 1988. Jazidas de bauxita da Zona da Mata de Minas Gerais. In Schobbenhaus C, CES Coelho coords. Principais depósitos minerais do Brasil, v.3. Brasília, Brasil. Departamento Nacional da Produção Mineral. p. 599-619.

Lu HF, ZH Wang, DE Campbell, H Ren, J Wang. 2011. Emergy and eco-exergy evaluation of four forest restoration modes in southeast China. Ecological Engineering 37: 277-285.

Lucas EJ, SR Belsham, EM Nic Lughadha, DA Orlovich, CM Sakuragui, MW Chase, PG Wilson. 2005. Phylogenetic patterns in the fleshy-fruited Myrtaceae - preliminary molecular evidence. Plant Systematics and Evolution 251: 35-5.

Marangon LC, JJ Soares, ALP Feliciano, CFLS Brandão. 2008. Regeneração natural em um fragmento de Floresta Estacional Semidecidual em Viçosa, Minas Gerais. Revista Árvore 32(1): 183-191.

Martins SV, SH Kunz. 2007. Use of evaluation and monitoring indicators in a riparian forest restoration project in Viçosa, southeastern Brazil. In Rodrigues RR, SV Martins, S Gandolfi eds. High diversity forest restoration in degraded areas. New York, USA. Nova Science Publishers. p. 261-273.

Martins SV. 2013. Recuperação de áreas degradadas: ações em áreas de preservação permanente, voçorocas, taludes rodo- viários e de mineração. Viçosa, Brasil. Aprenda Fácil. 264 p. Mikich SB. 2002. A dieta dos morcegos frugívoros (Mammalia, Chiroptera, Phyllostomidae) de um pequeno remanescente de Floresta Estacional Semidecidual do sul do Brasil. Revista Brasileira de Zoologia 19: 239-249.

Miranda Neto A, SV Martins, KA Silva, JM Gleriani. 2012. Estrato de regeneração natural de uma floresta restaurada com 40 anos. Pesquisa Florestal Brasileira 32(72): 409-420.

Missouri Botanical Garden. Consultado 10 mar. 2014. Disponible en http://www.tropicos.org.

Moreira FMS, JO Siqueira. 2006. Microbiologia e bioquímica do solo. 2. ed. Lavras, Brasil. Editora UFLA. 729 p.

Moreira PR. 2004. Manejo do solo e recomposição da vegetação com vistas a recuperação de áreas degradadas pela extração de bauxita, Poços de Caldas, MG. Tesis Doctor em Ciências Biológicas. Rio Claro, Brasil. Universidade Estadual Paulista. 155 p.

Mueller-Dombois D, H Ellenberg. 1974. Aims and methods of vegetation ecology. New York, US. John Wiley \& Sons. 547 p.

Newton AC. 2007. Forest ecology and conservation: a handbook of techniques. Oxford, UK. University Press. 454 p.

Oliveira WL, MB Medeiros, P Moser, R Pinheiro, LB Olsen. 2011. Regeneração e estrutura populacional de jatobá-damata (Hymenaea courbaril L.), em dois fragmentos com diferentes graus de perturbação antrópica. Acta Botanica Brasilica 25(4): 876-884.

Parrotta JA, OH Knowles, JM Wunderle Jr. 1997. Development of floristic diversity in 10-year-old restoration forests on a bauxite mined site in Amazonia. Forestry Ecology and Management 99: 21-42.

Rodrigues ER, R Monteiro, L Cullen Junior. 2010. Dinâmica inicial da composição florística de uma área restaurada na região do Pontal do Paranapanema, São Paulo, Brasil. Revista Árvore 34(5): 853-861.

Santos JF, R Valcarcel. 2011. Avaliação florística do estrato regenerante de reflorestamentos em área reabilitada na Mata Atlântica. Floresta e Ambiente 18(4): 390-401.

Shepherd GJ. 2010. Fitopac 2.1 - Campinas, Brasil. Departamento de Botânica, Universidade Estadual de Campinas.

Silva-Júnior MC, JM Felfili, BMT Walter, PE Nogueira, AV Rezende, RO Morais, MGG Nobrega. 2001. Análise da flora arbórea de Matas de Galeria no Distrito Federal: 21 levantamentos. In Ribeiro JF, CEL Fonseca, JC Sousa-Silva eds. Cerrado: caracterização e recuperação de Matas de Galeria. Planaltina, Brasil. Embrapa Cerrados. p. 143-191.

Sobral M, C Proença, M Souza, F Mazine, E Lucas. 2010. Myrtaceae. In Forzza RC et al. eds. Catálogo de plantas e fungos do Brasil. v. 02. Rio de Janeiro, Brasil. Jardim Botânico do Rio de Janeiro. p. 1301-1329.

Souza PB, AL Souza, WS Costa, RV Del Peloso, JM Lana. 2012. Florística e diversidade das espécies arbustivo-arbóreas regeneradas no sub-bosque de Anadenanthera peregrina (L.) Speg. Cerne 18(3): 413-421.

Souza PB, JAA Meira Neto, AL Souza. 2013. Diversidade florística e estrutura fitossociológica de um gradiente topográfico em floresta estacional semidecidual submontana, MG. Cerne 19(3): 489-499.

ter Braak CJF. 1995. Ordination. In Jongman RHG, CJF ter Braak, OFR van Tongeren eds. Data analysis in community and landscape ecology. Cambrigde, UK. Cambrigde University 
Press. p. 91-173.

van Andel J, J Aronson. 2012. Getting started. In van Andel J, Aronson $\mathrm{J}$ eds. Restoration ecology: the new frontier. Oxford, UK. Wiley-Blackwell. p. 3-8.

van der Pijl L. 1982. Principles of dispersal in higher plants. 3 ed. Berlin, Germany and New York, US. Springer-Verlag. $214 \mathrm{p}$.

Wortley L, J Hero, M Howes. 2013. Evaluating ecological restoration success: a review of the literature. Restoration Ecology 21(5): 537-543.

Recibido: 30.04 .14

Aceptado: 04.09.14 
